\title{
Stigma and gender dimension based on rural and urban communities in preventing HIV and AIDS in childbearing age couples in Banyumas Regency
}

\author{
Colti Sistiarani, Bambang Hariyadi, Munasib Munasib, Septi M. Sari \\ Jendral Soedirman University, Indonesia
}

\begin{abstract}
Introduction: Transmission of human immunodeficiency virus (HIV) and acquired immunodeficiency syndrome (AIDS) becomes a serious problem in Banyumas Regency, particularly in Cilongok and South Purwokerto sub-districts. The aim of this study was to map the stigma and analyze the gender dimensions according to access, roles, benefit, and control.

Material and methods: This was a cross-sectional study, with a quantitative approach. The population and sample taken in a quantitative research included 193 participants of fertile age couples (couples of childbearing age) in Banyumas Regency from Cilongok and South Purwokerto sub-district. Paired $t$-test was used for data analysis.

Results: Based on the research, most of the respondents were between 36 and 49 years old (66.33\%). Men and women ratio were almost equal, resulting in $49.74 \%$ and $50.26 \%$, respectively. The majority of respondents had a high level of education (39.37\%), not working resulted in $53.88 \%$, while those having children accounted for $67.87 \%$. The outcomes of the study revealed that there was no stigma reduction in role and gender equality improvement according to sex category. There were differences in role reduction stigma between urban and rural communities, and also differences in the role of gender equality improvement in urban and rural areas.

Conclusions: There are differences in role reduction stigma and also discrepancies in the role of gender equality improvement between urban and rural communities. It is important to pay attention to residence area factor in the effort of implementing a prevention program for HIV and AIDS. It can be related to the prevailing approaches to HIV and AIDS prevention policies and programs.
\end{abstract}

HIV AIDS Rev 2020; 19, 1: 61-66 DOI: https://doi.org/10.5114/hivar.2020.93178

Key words: gender, stigma, rural, urban.

\section{Introduction}

Stigma and gender inequality is a problem in preventing human immunodeficiency virus (HIV) and acquired immunodeficiency syndrome (AIDS) transmission. Percep- tions and negative responses, differences among individuals, families, and communities as well as age, race, and social status relate to that aspect. The stigma associated with HIV is driven by a variety of factors including the fear of contracting HIV based on sex, sexual orientation, and drug

Article history:

Received: 05.12.2017

Received in revised form: 01.06.2019

Accepted: 18.06.2019

Available online: 06.02.2020
International Journal of HIV-Related Problems

HIV \& AIDS

R e v i e w 
use. The stigma associated with HIV is very destructive, and occurs continuously and unavoidably as well as significant gender-related inequalities [1].

These existing gender-based inequalities are aggravated by HIV and AIDS. Moreover, the driving factor in the household life aspect is strongly related including women's unequal financial incomes, uneven opportunity to earn, and lack of control over resources and assets. Social and political factors are responsible for violence, which women experience, lack of decision making in sexual relationships, no legal inheritance rights, limitations in health choices and their sexual and reproductive rights [2].

Efforts to reduce stigma and to increase gender equality are important, because these are the main points in handling AIDS epidemic globally. The results of previous studies stated that the prevention behavior of HIV and AIDS in housewives has been sufficient. However, housewives perceive themselves as vulnerable; they recognize HIV as a serious illness and understand the cues to avoid contracting HIV, but housewives perceive that prevention behavior as not useful. The research results show that there is a relationship between cues to act and HIV and AIDS prevention behaviors [3].

Six sub-districts in Banyumas Regency are included in the red zone due to many cases of HIV and AIDS in that region. These areas include Baturraden, South Purwokerto, Cilongok, Wangon, Jatilawang, and Banyumas sub-districts. To minimize the potential spread of the virus, efforts has been initiated to hold the community incorporated in a place named the Center for Public Health Information (CPHI). The Citizens Care AIDS Program (CCAP) established by the AIDS Prevention Commission (KPA) to prevent the spread of HIV/AIDS are initiated by the district government. Anti-HIV/AIDS groups joined in WPA in some villages has been established [4].

People, especially in rural communities, need additional knowledge of gender equality. The understanding of positive gender equality in society has many benefits in life, especially in reducing cases of gender injustice and domestic issues. Gender is an important determinant of health and disease, and gender awareness contributes to equity in health, intending improved health of both men and women $[5,6]$.

Women empowerment is needed as an effort to overcome the broader impact of HIV vulnerability. HIV-infected women have the potential to transmit the disease to their children. Scaling up intervention program seeks to empower women by increasing they self-esteem, changing gender roles and relationships between men and women, reducing gender-based violence, building assertiveness and safe negotiating skills, and provide responsible sexual behavior, including condom use [7].

HIV and AIDS stigma exists and the efforts to reduce the stigma are targeted at various levels of individuals, interpersonal relations (family, friends, social networks), organizations, communities, and public policy. The individual level emphasizes on enhancing individual knowledge about HIV transmission, prevention and care, and the right to access services and laws. Stigma reduction campaigns at the family level are stressed on social support efforts [8].
The approach program to reduce the level of women's discrimination in the context of HIV seeks to overcome gender inequality and gender-based violence, both as a reason and consequence caused by HIV infection. The program overcomes the women and girls inequalities regarding sex and reproduction, decision-making, gender barriers to health services, inheritance discrimination, property ownership, marriage, divorce, and custody, sexual and other violent practices as well as lack of equal access to educational and economic opportunities [9].

The social process of stigmatization and discrimination can have a complex and very bad effect on health and welfare of families and communities. It is needed for interventions to reduce the stigma and discrimination that can impede children's health and wellbeing in low- and middle-income countries, focusing on nutrition, HIV/AIDS, neonatal survival, infants' health, and early childhood development.

HIV/AIDS, gender, and stigma are all correlated. It can be explained that the pandemic of HIV/AIDS is driven by aggravated gender inequality. Changing gender disparities is not only difficult, but may not be the top priority regarding women and HIV-related stigma. Rural women in South Africa consider AIDS stigma intervention as unimportant efforts to overcome gender inequalities directly. They prefer to prioritize efforts to overcome more urgent problems such as poverty and health $[10,11]$.

The emergence of stigma and gender bias at the individual level is closely related to socio-cultural factors and community. In this research, individual roles in preventing stigma and the role of increasing gender equality based on access, role, benefit, and control were evaluated. This assessment was completed in order to consider the individual roles based on urban and rural areas. Differences in the role of stigma reduction and the role of gender equality enhancement can be use to plan individual HIV and AIDS prevention programs.

A research about stigma and gender dimension related to HIV has been completed before, but to our knowledge, there is no study on differences between stigma and gender dimension in the rural and urban. It is important to analyze the differences between stigma and gender dimension of HIV in the rural and urban regions, because it relates to HIV and AIDS prevention efforts. Furthermore, knowing the differences will facilitate a choice of action that is suitable for particular area based on its characteristics and disparities.

\section{Material and methods}

Quantitative method with cross-sectional approach was used in this study, including 193 participants from childbearing age couples (CAC) group from Banyumas Regency. Sampling technique was completed by simple random sampling. Inclusion criteria comprised of CAC who lived in a house with a partner. In this case, the interview could be represented by husband/wife, willing to participate in the study by signing an informed consent. The exclusion criteria included CAC who were not domiciled, and remained in Cilongok and South Purwokerto sub-district. 
Data collecting technique used in this study was an interview with a questionnaire that was in the form of a closed question to identify the role of HIV and AIDS stigma reduction. The role in reducing stigma was the role to avoid the attitude or negative behavior of an individual when dealing with people with HIV and AIDS (ODHA) among others, with respect for rights, sympathy, awareness, and confidentiality. Additionally, data collecting technique with the use of questionnaires aimed to identify the gender dimension in HIV and AIDS prevention, and was divided into open variables such as access to information and health services to prevent HIV and AIDS. Variables in role were the participation in preventing HIV and AIDS including decision-making, communication, and role-sharing negotiations. The variable benefit was the existence of benefits obtained both directly and indirectly in the prevention of HIV and AIDS. The control variable was individuals increasing awareness and provide feedback to couples about HIV and AIDS prevention efforts such as the fulfillment of reproductive rights. Also, the study identified the knowledge of respondents on HIV and AIDS stigma and gender knowledge related to HIV and AIDS.

Ethical clearance approval was completed in the Ethics Commission of the Faculty of Medicine, University of General Soedirman. The ethical clearance number was Ref 1492/ KEPK/IV/2017, issued on April 11, 2017. The location of validity and reliability test was done in sub-district, which has similar characteristics as the location used in the study - East Purwokerto and Ajibarang sub-districts. The instrument was tested by the Pearson's product-moment correlation to confirm the statement validity. Reliability test was also completed, and the results shown that the value of Cronbach alpha $>0.7$, so that the questionnaire was reliable. The results of reliability are presented in Table 1 .

Univariate analysis used for data analysis included sociodemographic characteristic. Bivariate analysis was applied to examine the different roles of stigma reduction and gender dimension based on access, role, benefit, and control as well as the role in improving gender equality based on rural and urban area characteristics using different test with two mean independent $t$-tests. Multivariate logistic regression analysis was applied to identify the factors influencing the role of stigma reduction and gender enhancement role. These factors include demographic characteristics such as gender, residence, number of children, occupation, education, and knowledge level.

\section{Results}

Based on the research, most of the respondents were between 36 and 49 years old (66.33\%). Men and women ratio were almost equal, resulting in $49.74 \%$ and $50.26 \%$, respectively. The majority of respondents had a high level of education (39.37\%), not working resulted in 53.88\%, while those having children accounted for $67.87 \%$. Table 2 describes stigma reduction scores and gender dimensions that include access, roles, benefits, and controls. The average stigma reduction role score was 55.75 and the standard deviation score was 10.21. Table 3 presents the results of bivariate analysis and shows that there is a difference between the role of stigma reduction and the role of gender equality dimension in fertile couples who live in rural and urban areas.

Based on Tables 4 and 5 it can be explained that there is a relationship between knowledge of CAC on gender and HIV/AIDS with the role of increasing gender equality, but there is no correlation between knowledge of HIV and AIDS stigma with stigma reduction efforts in EFA in Banyumas sub-district.

Table 6 describes the factors that influence the role of increasing gender equality including the residence and the number of children. Area factor of residence is the most influential factor in the role of increasing gender equality.

\section{Discussion}

The role of stigma reduction and the role of gender equality increase varied in rural and urban areas. There was no difference in the role of stigma reduction by sex, level of employment, level of education, number of children, and knowledge; the characteristics share the equivalent stigma reduction scores.

Factors affecting stigma against people living with HIV/ AIDS (PLWHA) in Grobogan Regency is both the attitude of a family and perception of a respondent to PLWHA. Women living with HIV recognize the perceived HIV stig-

Table 1. Results of the reliability test

\begin{tabular}{l|c}
\hline Variable & Cronbach $\boldsymbol{\alpha}$ assessment \\
\hline Stigma reduction & 0.7495 \\
\hline Gender equality role & 0.7551 \\
\hline Knowledge & 0.726 \\
\hline
\end{tabular}

Table 2. Descriptive results of stigma reduction score and gender dimension, $n=193$

\begin{tabular}{|c|c|c|c|c|}
\hline Variable & Mean & SD & Skor Min & Skor Max \\
\hline Stigma reduction & 55.75 & 10.21 & 20 & 80 \\
\hline Gender access dimensions & 22.72 & 4.72 & 9 & 35 \\
\hline Role & 24.65 & 4.15 & 13 & 35 \\
\hline Benefits & 7.5 & 1.39 & 2 & 10 \\
\hline Control & 21.77 & 3.88 & 7 & 30 \\
\hline
\end{tabular}


ma of the community (a belief that in their community, HIV infection among women is associated with sex work and many sexual partners) and they perceive gender norms of the community (the belief that traditional gender norms

Table 3. Results of difference analysis of CAC groups in rural and urban areas

\begin{tabular}{|c|c|c|c|c|}
\hline Variable & $n$ & Mean & SD & Sig. \\
\hline \multicolumn{5}{|c|}{ Gender equality dimension } \\
\hline \multicolumn{5}{|l|}{ Access } \\
\hline Rural & 93 & 22.92 & 4.44 & 0.563 \\
\hline Urban & 100 & 22.53 & 4.97 & \\
\hline \multicolumn{5}{|l|}{ Role } \\
\hline Rural & 93 & 24.01 & 4.69 & 0.040 \\
\hline Urban & 100 & 25.25 & 3.50 & \\
\hline \multicolumn{5}{|l|}{ Benefits } \\
\hline Rural & 93 & 7.36 & 1.47 & 0.189 \\
\hline Urban & 100 & 7.63 & 1.31 & \\
\hline \multicolumn{5}{|l|}{ Control } \\
\hline Rural & 93 & 21.25 & 4.24 & 0.076 \\
\hline Urban & 100 & 22.25 & 3.46 & \\
\hline \multicolumn{5}{|c|}{ Stigma reduction } \\
\hline Rural & 93 & 54.03 & 10.83 & 0.024 \\
\hline Urban & 100 & 57.35 & 9.36 & \\
\hline
\end{tabular}

Table 4. Knowledge with stigma reduction

\begin{tabular}{l|c|c|c|c}
\hline \multirow{2}{*}{ Knowledge } & \multicolumn{2}{|c|}{ Stigma reduction } & \multirow{2}{*}{$\begin{array}{c}\text { Total, } \\
n(\%)\end{array}$} & $\begin{array}{c}p \\
\text { value }\end{array}$ \\
\cline { 2 - 4 } & Less, $n(\%)$ & Good, $n(\%)$ & & \\
\hline Less & $50(52.1)$ & $46(47.9)$ & $96(100.0)$ & \multirow{2}{*}{1.000} \\
\hline Good & $51(52.6)$ & $46(47.4)$ & $15(100.0)$ & \\
\hline
\end{tabular}

Table 5. Knowledge with the role of gender equality improvement

\begin{tabular}{l|c|c|c|c}
\hline \multirow{2}{*}{ Knowledge } & \multicolumn{2}{|c|}{$\begin{array}{c}\text { The role of gender } \\
\text { equality }\end{array}$} & \multirow{2}{*}{$\begin{array}{c}\text { Total, } \\
n(\%)\end{array}$} & $\begin{array}{c}p \\
\text { value }\end{array}$ \\
\cline { 2 - 3 } & Less, $n(\%)$ & Good, $n(\%)$ & & \\
\hline Less & $51(53.1)$ & $45(46.9)$ & $96(100.0)$ & \multirow{2}{*}{0.037} \\
\hline Good & $36(37.1)$ & $61(62.9)$ & $97(100.0)$ & \\
\hline
\end{tabular}

such as adherence to a male husband/sexual partner are required, and social status is lost if a person does not have children). Interventions to promote disclosure among women should include community-level interventions to reduce stigma and promote gender equality $[12,13]$.

Another study illustrates supposed change in stigma over a one-year period at two sites in Kenya, one city and one rural area. The findings suggested that the feelings affected by HIV stigma may be different from the social and gender context. Sex and rural/urban differences involve the experience of sensing HIV-related stigma. City people experience significant changes in sensing HIV-related stigma over time, unlike in rural areas. The experience of stigma shows significant difference in rural and urban as the areas vary in social networks [14].

The research shows that cultural explanations can be a source of stigma. A woman who does not deviate from the norm would be more likely to believe her husband, and the woman is afraid that her reputation would be broken. Additionally, she keeps the secret to avoid involving her family and her husband's family in negotiations of cultural sanctions. One of the main explanations in the mountains is that women are vectors for disease. For example, a man is considered to feel dirty being HIV-positive, because of contracting HIV from having sex with a woman. Women's endeavors to protect themselves and stay connected socially from family and culture [15].

The absence of sex-based differences in stigma reduction is due to both men and women having an equal role in the concept of looking at HIV stigma. Information on prevention of HIV transmission has reached the layers of men and women groups, so that they perform almost equal roles. The absence of a culture that can be a source of stigma is the reason for the absence of different roles in stigma reduction in men and women. Women have sought to protect themselves and conduct preventive behaviors of HIV and AIDS transmission [16].

The results of this study indicated that the level of education in urban groups in the majority of women (44.9\%) was high school education level, but a level of knowledge about the stigma was only $51 \%$. In the rural group, the result of the research shows that most of the women had an equal education level of SMP (52.1\%), and knowledge level about stigma classified as a less good category - $58.3 \%$. High level of education did not mean having good knowledge of stigma and the role it plays in reducing HIV-related stigma.

This characteristic can be related to the result of this research, which was the difference of role of stigma reduction and the role of increasing gender equality in rural and ur-

Table 6. Final results of multivariate analysis

\begin{tabular}{|l|c|c|c|c|c|c}
\hline Step 1(a) & B & S.E. & Wald & Df & Sig. & Exp(B) \\
\hline Residential area & 0.780 & 0.299 & 6.802 & 1 & 0.009 & 0.181 \\
\hline Number of children & 0.624 & 0.319 & 3.835 & 1 & 1.867 \\
\hline Constant & -2.047 & 0.752 & 7.405 & 1 & 0.007 \\
\hline
\end{tabular}


ban communities. From the data, it can be compared that the level of education of men was mostly high school in both urban and rural groups, and have a good level of knowledge in both groups. It can be explained that these characteristics influence the role of stigma reduction in rural and urban groups.

There is a negative correlation between citizens' awareness about HIV/AIDS, HIV-related attitudes, negative perceptions of people with symptoms of HIV/AIDS, and discriminatory attitudes toward people living with HIV and AIDS. Public perceptions about HIV/AIDS explain 23.7\% variance of discriminatory attitudes toward PLWHA. Negative public perceptions about HIV/AIDS in Iran are associated with discriminatory attitudes toward PLWHA, and cultural belief in Iran tend to stigmatize and discriminate people living with HIV and AIDS [17].

Gender inequality affects HIV prevention, detection, and management. Malavi et al's study (2014) states that most HIV-infected men perform HIV testing more than women, while women are more likely to have HIV testing done after knowing their partner's HIV-positive status. Women report greater risks for stigma than men, but men changed their sexual behavior after being diagnosed with HIV, compared to women. There is a need for a gender-based approach to HIV prevention and stigma reduction [18].

Attempts to remove stigma and discrimination are important because it is believed to suppress the increasing number of HIV and AIDS cases. Socialization of HIV and AIDS to the community to increase the knowledge and awareness is not enough. Another urgent thing that needs to be accomplished is to eliminate negative assumptions about HIV/ AIDS and PLWHA. Leaders who have the ability to remove the stigma and discrimination against people living with HIV are a civil society. This is based on the fact that it is difficult to rely solely on the government alone to eradicate, obstruct, and to reduce the stigma and discrimination associated with HIV and AIDS. The problem of stigma and intolerance is suspected to be closely related to the issue of sexuality, gender, ethnicity, poverty as well as the fear of being infected with the virus. The issue of stigma and discrimination against people with HIV and AIDS is also linked to gender stigma. The impact of this stigma and discrimination is more severe-faced by women living with HIV, because it causes unfavorable economic, educational, social, and cultural problems as well as lacks the access to information and services [19].

The importance of stigma in HIV response needs to be taken into account in HIV prevention. The significance of integration of stigma reduction and discrimination to address the problems of HIV that are encountered in very complex problems should be at the core of prevention efforts. These priorities can be represented in appropriate funding, policies, research, and programs [20].

The prevalence of interpersonal discrimination in all countries was $34.6 \%$, with women significantly more likely to experience interpersonal discrimination than men. The prevalence of internalized stigma varies across countries, ranging from 9.6\% (Malawi) to $45.0 \%$ (Burkina Faso).
The prevalence of health service discrimination is $10.4 \%$ in all countries. In a multivariate analysis, there is an influence between disclosure and interpersonal discrimination and the use of support groups, and a positive relationship between both internalized stigma and health care discrimination and referral for treatment [21].

This study divides the dimensions of increasing gender equality based on access, roles, benefits, and control. The results of this study conclude that there are differences in the role of increasing gender equality in individuals living in rural and urban areas. Based on a multivariate analysis of factors that influence the role of gender equality improvement among other areas of residence and number of children, respondents mostly had children less than or equal to 2. Determinants of gender analysis are factors of access, participation, control, and benefits. Four things are strongly influenced by the understanding of religion, social construction, and gender relations that occur in the family. The pattern of gender relations and construction of social community also causes poor households to access the information and benefits of the program, how to contribute, participate, and control/evaluate the program [22].

Differences in the role of increasing gender equality in rural and urban groups can be attributed to differences in the concept of women's empowerment in both areas. Among women $38.77 \%$ in urban area are professionally working, while in rural area - only $8.3 \%$.

According to Hastuti and Respati in Sari and Suwartiningsih, patriarchal culture dominating the Javanese society is placing a woman with a main task as a wife. Both housewives and women need to be empowered to have the right to reproductive health. Women's empowerment activities do not mean not involving men. This needs to be changed by using a strategy that emphasizes more attention to the problem of male and female relationships. The root of the problem of women's helplessness in protecting themselves from HIV/ AIDS is their lack of access to the resources and patriarchal cultural environment [23].

Empowerment needs sustainable steps including siding (there must be siding on women through empowerment) and preparation (empowerment demands women's ability to access, participate, control, and benefit). Women's empowerment deals with the value system of women and men in the community in relation to the distribution of power [24].

The influence of number of children and residence areas with the role of increasing gender equality shows that CAC having more than 2 children are found in an urban area than rural. The number of children less than or equal to 2 in urban and rural areas is comparable. The number of children relates to family role-sharing efforts. Equitable division of roles to husbands and wives is an aspect that can be related to efforts to increase gender equality.

Partnerships in the division of the role of husband and wife related to cooperation in carrying out family functions with behavioral components included contributions of ideas, attention, moral, and material assistance, advice based on knowledge gained, help of energy, and time. This 
is associated to the role of increasing gender equality to prevent HIV and AIDS. Increased gender equality begins at the family level, as the smallest unit in the community represents an individual's resilience to prevent HIV and AIDS transmission. Gender equality in the family forms good gender cooperation in all aspects of life such as economic, social, cultural, and other societal characteristics at all levels of society. It can be concluded that a society free of HIV and AIDS can be achieved through strategies to improve family welfare, with harmonious gender relations in the community [25].

\section{Conclusions}

The results show that there is a difference in the role of stigma reduction and the role of increasing gender equality groups in urban and rural areas. There is a relationship between gender knowledge and the role of increasing gender equality. Factors influencing the role of increasing gender equality are the factors of residence and number of children.

Based on this research, it is important to pay attention to the residence area factor in the effort to implement HIV and AIDS prevention program. Differences in the role of stigma reduction and the role of increasing gender equality in urban and rural communities can be related to the prevailing approaches to HIV and AIDS prevention policies and programs.

\section{Conflict of interest}

The authors declare no conflict of interest with respect to the research, authorship, and/or publication of this article.

\section{References}

1. Sayles JN, Ryan GW, Silver JS, Sarkisian CA, Cunningham WE. Experiences of social stigma and implications for healthcare among a diverse population of HIV positive adults. J Urban Health 2007; 84: 814-828.

2. Holmes R, Jones N. Gender inequality, risk and vulnerability in the rural economy: refocusing the public works agenda to take account ofeconomic and social risks. Overseas Development Institute, December 2009.

3. Sistiarani C, Gamelia E, Anandari D. HIV And AIDS prevention behavior of housewife in South Purwokerto District, Indonesia. Laporan Penelitian Lembaga Penelitian dan Pengabdian Kepada Masyarakat, Purwokerto 2016.

4. Dinas Kesehatan Kabupaten Banyumas, Profil Kesehatan Kabupaten Banyumas. Dinas Kesehatan Kabupaten Banyumas, 2015.

5. Fauziah N, Mulyana, Raharjo TS. Pengetahuan Masyarakat Desa tentang Kesetaraan Gender. Prosiding Riset dan Pengabdian Kepada Masyarakat 2016; 2.

6. Verdonk P, Benschop YW, de Haes HC, Lagro-Janssen TL. From gender bias to gender awareness in medical education. Adv Health Sci Educ Theory Pract 2009; 14: 135-152.

7. Hope R. Women's empowerment and HIV prevention. DAC Network on Gender Equality, 27-29 June 2007.

8. De Carlo P, Ekstrand M. How does stigma affect HIV prevention and treatment. Center for AIDS Prevention Studies Prevention Research Center, October 2016.
9. United Nation AIDS. Key Programmes to Reduce Stigma and Disscrimination and Increase Access to Justice in National HIV Responses. UNAIDS, May 2012.

10. United Nation Development Fund For Women, World Health Organization, Facing the Future Together: Report of the Secretary General's Task Force on Women, Girls and HIV/AIDS in Southern Africa. UNIFEM and WHO, Geneva 2004.

11. Campbell C, Gibbs A. Stigma, gender and HIV: case studies of intersectionality. In: Boesten J, Poku NK (eds.). Gender and HIV/AIDS: Critical Perspectives from the Developing Eorld. Ashgate, Surrey 2009; 29-46.

12. Bisola OO, Subash P, Srithanaviboonchai K, et al. Safren, Community Cultural Norms, Stigma and Disclosure to Sexual Partners among Women Living with HIV in Thailand, Brazil and Zambia (HPTN 063). HIV Prevention Trials Network, 2016.

13. Shaluhiyah Z, Musthofa SB, Widjanarko B. Stigma Masyarakat terhadap Orang dengan HIV/AIDS. Kesmas: Jurnal Kesehatan Masyarakat Nasional 2015; 9: 333-339.

14. Yebei NV, Fortenberry JD, Ayuku DO. Felt stigma among people living with HIV/AIDS in rural and urban Kenya. Afr Health Sci 2008; 8: 97-102.

15. Butt L, Morin J, Numbery G, et al. Stigma dan HIV/AIDS di Wilayah Pegunungan Papua. Pusat Studi Kependudukan - UNCEN, Abepura, Papua dan University of Victoria, Canada 2010.

16. United Nation Programme on HIV/AIDS, World Health Organization, Addressing Gender Inequalities: Strengtening HIV/AIDS Programing for Women and Girl. UNAIDS \& WHO, 2007.

17. Masoudnia E. Public perceptions about HIV/AIDS and discriminatory attitudes toward people living with acquired immunodeficiency syndrome in Iran. SAHARA-J 2015; 12: 116-122.

18. Malavé S, Ramakrishna J, Heylen E, Bharat S, Ekstrand ML. Differences in testing, stigma, and perceived consequences of stigmatization among heteroseksual men and women living with HIV in Bengaluru, India. AIDS Care 2014; 26: 396-403.

19. Latifa A, Purwaningsih SS. Peran Masyarakat Madani Dalam Mengurangi Stigma Dan Diskriminasi Terhadap Penderita HIV \& AIDS. Jurnal Kependudukan Indonesia 2011; 6: 51-76.

20. Stangl AL, Lloyd JK, Brady LM, Holland CE, Baral S. A systematic review of interventions to reduce HIV-related stigma and discrimination from 2002 to 2013: how far have we come? J Int AIDS Soc 2013; 16 (3 Suppl 2): 18734.

21. Neuman M, Obermeyer MC; MATCH Study Group. Experiences of stigma, discrimination, care and support among people living with HIV: a four country study. AIDS Behav 2013; 17: 1796-1808.

22. Esariti L. Determinan Analisis Gender Pada Pemberdayaan Masyarakat Miskin Perkotaan. Ruang 2016; 2: 751-760.

23. Sari BW, Suwartiningsih S. Pemberdayaan Perempuan Dalam Penanggulangan HIV dan AIDS Di Kota Salatiga. KRITIS, Jurnal Studi Pembangunan Interdisiplin 2013; 22: 118-135.

24. Nugroho R. Gender dan Strategi Pengarusutamaannya di Indonesia, Yogyakarta: Pustaka Pelajar, Cetakan II, 2011.

25. Puspitawati H. Gender dan Keluarga: Konsep dan Realita di Indonesia. PT IPB Press, Bogor 2012. 